\title{
Role of NAD(P)H oxidase in the tamoxifen-induced generation of reactive oxygen species and apoptosis in HepG2 human hepatoblastoma cells
}

\author{
YS Lee ${ }^{1}$, YS Kang ${ }^{1}$, SH Lee ${ }^{1}$ and JA Kim ${ }^{\star, 2}$ \\ 1 Department of Physiology, College of Medicine, Kwandong University, \\ Kangnung 210-701, Korea \\ 2 College of Pharmacy, Yeungnam University, Kyongsan, Korea \\ * Corresponding author: JA Kim, PhD, College of Pharmacy, Yeungnam \\ University, Kyongsan, 712-749, Korea \\ Tel: 82-53-810-2816; Fax: 82-53-811-3871; E-mail: jakim@yu.ac.kr
}

Received 22.2.00; revised 3.5.00; accepted 11.5.00

Edited by A Finazzi-Agio

\begin{abstract}
Previously, tamoxifen (TAM) has been shown to induce apoptosis through elevation of intracellular $\mathrm{Ca}^{2+}$ in HepG2 human hepatoblastoma cells. In this study we investigated the role of reactive oxygen species (ROS) in the TAM-induced apoptosis, and interrelationship between intracellular $\mathrm{Ca}^{2+}$ and ROS. TAM induced a slow and sustained increase in intracellular ROS level. An antioxidant, $\mathrm{N}$-acetylcysteine significantly inhibited both ROS production and apoptosis induced by TAM, suggesting that ROS may play an essential role in the TAM-induced apoptosis. In a time frame ROS generation followed intracellular $\mathrm{Ca}^{2+}$ increase, and the extracellular and intracellular $\mathrm{Ca}^{2+}$ chelation with EGTA and BAPTA/AM, respectively, completely inhibited the TAMinduced ROS production, indicating that intracellular $\mathrm{Ca}^{2+}$ may mediate the ROS generation. Inhibitors of $N A D(P) H$ oxidase, diphenylene iodonium, phenylarsine oxide and neopterine, significantly blocked the TAM-induced ROS generation and apoptosis, implying that this oxidase may act as a source enzyme for the production of ROS. These results suggest that non-phagocytic $N A D(P) H$ oxidase may play a novel role as a mediator of the apoptosis associated with intracellular $\mathrm{Ca}^{2+}$ in HepG2 cells. Cell Death and Differentiation (2000) 7, 925-932.
\end{abstract}

Keywords: tamoxifen; apoptosis; reactive oxygen species; intracellular $\mathrm{Ca}^{2+} ; \mathrm{NAD}(\mathrm{P}) \mathrm{H}$ oxidase

Abbreviations: BAPTA/AM, bis-(o-aminophenoxy)-ethane$\mathrm{N}, \mathrm{N}, \mathrm{N}, \mathrm{N}$-tetraacetic acid/acetoxymethyl ester; EGTA, ethylene glycol-bis-(aminoethyl ether)N,N,N,N-tetraacetic acid; ER, estrogen receptor; DCFH-DA, 2',7'-dichlorofluorescin diacetate; DPI, diphenylene iodonium; FCCP, carbonylcyanide-p-(trifluoromethoxy)phenylhydrazone; Fura-2/AM, 1-(2,5-Carboxyoxazol-2yl-6-aminobenzfuran-5-oxyl)-2-(2'-amino-methylphenoxy)-ethane -N,N,N,N-tetraacetoxylmethyl ester; NAC, N-acetylcysteine; NEO, $D-(+)$-neopterine; NMMA, $N^{G}$-monomethyl-L-arginine; PAO, phe- nylarsine oxide; PI, propidium iodide; ROS, reactive oxygen species; TAM, tamoxifen

\section{Introduction}

Tamoxifen (TAM) has been used to treat breast cancer, ${ }^{1}$ with the potential for application as a cancer-preventing agent. ${ }^{2}$ Although the antiestrogenic properties of TAM appear to be responsible for the anticancer activities of TAM in breast cancer, ${ }^{3}$ the exact mechanisms of the actions of TAM are not yet clearly understood.

Apoptosis is a highly organized cell death process characterized by early and prominent condensation of nuclear chromatin, loss of plasma membrane phospholipid asymmetry, activation of proteases and endonucleases, enzymatic cleavage of the DNA into oligonucleosomal fragments, and segmentation of the cells into membranebound apoptotic bodies. ${ }^{4}$ TAM has been shown to induce apoptotic cell death in many types of tumor cells regardless of existence of estrogen receptor (ER).$^{5-8}$ Although the signal transduction mechanisms by which TAM induces apoptosis in ER-negative tumor cells are essentially unknown, it is found to be associated with activation of the transcription factor NF- $\kappa \mathrm{B},{ }^{7}$ or increased c-myc expression. ${ }^{8}$ Recently, we have also reported that TAM induces apoptosis through the activation of intracellular $\mathrm{Ca}^{2+}$ signal in ER-negative HepG2 human hepatoblastoma cells. ${ }^{9}$

Accumulating evidence implies that intracellular $\mathrm{Ca}^{2+}$ is commonly involved in the mechanism of apoptosis. ${ }^{10}$ One of the targets for elevated intracellular $\mathrm{Ca}^{2+}$ is the activation of the $\mathrm{Ca}^{2+}$-dependent protein kinases and phosphatases ${ }^{11}$ which has been seen during apoptosis. ${ }^{12}$ Direct activation of the $\mathrm{Ca}^{2+}$-dependent proteinase may represent another target for intracellular $\mathrm{Ca}^{2+}$ action in apoptosis. ${ }^{13} \mathrm{Ca}^{2+} / \mathrm{Mg}^{2+}$-dependent endonuclease whose activation results in DNA fragmentation, the most characteristic biochemical feature of apoptosis, ${ }^{14}$ and $\mathrm{Ca}^{2+}$-dependent transglutaminase which is highly activated in apoptotic cells, ${ }^{15}$ also appear to be a target for $\mathrm{Ca}^{2+}$ action. ${ }^{16,17}$ The in vitro antitumor actions of TAM have been explained by its ability to perturb intracellular $\mathrm{Ca}^{2+}$ homeostasis. ${ }^{9,18}$ In HepG2 cells we have found that TAM induced a sustained $\mathrm{Ca}^{2+}$ influx through activation of non-specific cation channels leading to apoptotic cell death. ${ }^{9}$

There are numerous reports showing that oxidants kill cells by inducing apoptosis. ${ }^{19-21}$ In addition, oxidative stress is proposed as a common mechanism by which various agents induce apoptosis. ${ }^{22}$ Recently, reactive oxygen species (ROS) have also been demonstrated to 
play an essential role in apoptosis induced by TAM in ERnegative human cancer cells. ${ }^{7,23}$

Intracellular $\mathrm{Ca}^{2+}$ appears to be essential for generation of ROS in many cell types, including mitogen-activated human lymphocytes ${ }^{24}$ and growth factor-stimulated human keratinocytes. ${ }^{25}$ Extracellular $\mathrm{Ca}^{2+}$ influx is necessary for ROS generation during respiratory burst in human neutrophils. ${ }^{26}$ ROS production stimulated by excitotoxin is dependent on intracellular $\mathrm{Ca}^{2+}$ in rat cerebellar granule cells. $^{27}$

Based on these previous findings, we hypothesized that TAM induces apoptosis through ROS generation mediated by elevated intracellular $\mathrm{Ca}^{2+}$. To verify this hypothesis, in this study we investigated (i) the role of ROS in the TAMinduced apoptosis in ER-negative HepG2 human hepatoblastoma cells, (ii) the cause-and-effect relationship between intracellular $\mathrm{Ca}^{2+}$ and ROS acting as a mediator of apoptosis, and (iii) the potential sites of ROS generation induced by TAM in the HepG2 cells.

\section{Results}

\section{Induction of apoptotic cell death by TAM}

We have previously reported that TAM induced apoptotic cell death in time- and concentration-dependent manners in the HepG2 cells. ${ }^{9}$ In this study we confirmed the apoptotic activity of TAM in the cells. TAM induced DNA fragmentation in a concentration-dependent manner studied by agarose gel electrophoresis as depicted in Figure 1A. This effect of TAM was prominent at the concentration of $30 \mu \mathrm{M}$. TAM also induced loss of phospholipid asymmetry, resulting in appearance of phosphatidylserine on the outer layer of the plasma membrane detected by annexin- $\mathrm{V}$ binding, as depicted in Figure 1B. Furthermore, TAM induced apoptosis in a time-related manner tested by flow cytometry by determining hypodiploid DNA content stained with $\mathrm{PI}^{28}$ as shown in Figure 1C. Taken together, these results indicate that TAM induced apoptotic cell death in the HepG2 cells.

\section{Role of ROS in the TAM-induced apoptosis}

To determine the role of ROS in the TAM-induced apoptosis of HepG2 cells, we first examined whether TAM generates ROS assessed by $2^{\prime}, 7^{\prime}$-dichlorofluorescin diacetate (DCFH) fluorescence. ${ }^{29}$ As shown in Figure $2 \mathrm{~A}$, TAM $(30 \mu \mathrm{M})$ induced a slow and sustained increase in intracellular ROS level, and this increase continued for at least $1 \mathrm{~h}$, depicted in Figure 2B. The TAM-generated ROS was completely inhibited by an antioxidant, $\mathrm{N}$-acetylcysteine (NAC) $(50 \mathrm{mM})$ as illustrated in Figure $2 \mathrm{~B}$. To determine the role of ROS in the TAM-induced apoptosis, we investigated whether NAC could suppress the apoptosis induced by TAM. As shown in Figure 2C, NAC $(50 \mathrm{mM})$ significantly lowered hypodiploid DNA content induced by TAM, indicating that ROS may be involved in the mechanism of the TAM-induced apoptosis in the HepG2 cells.
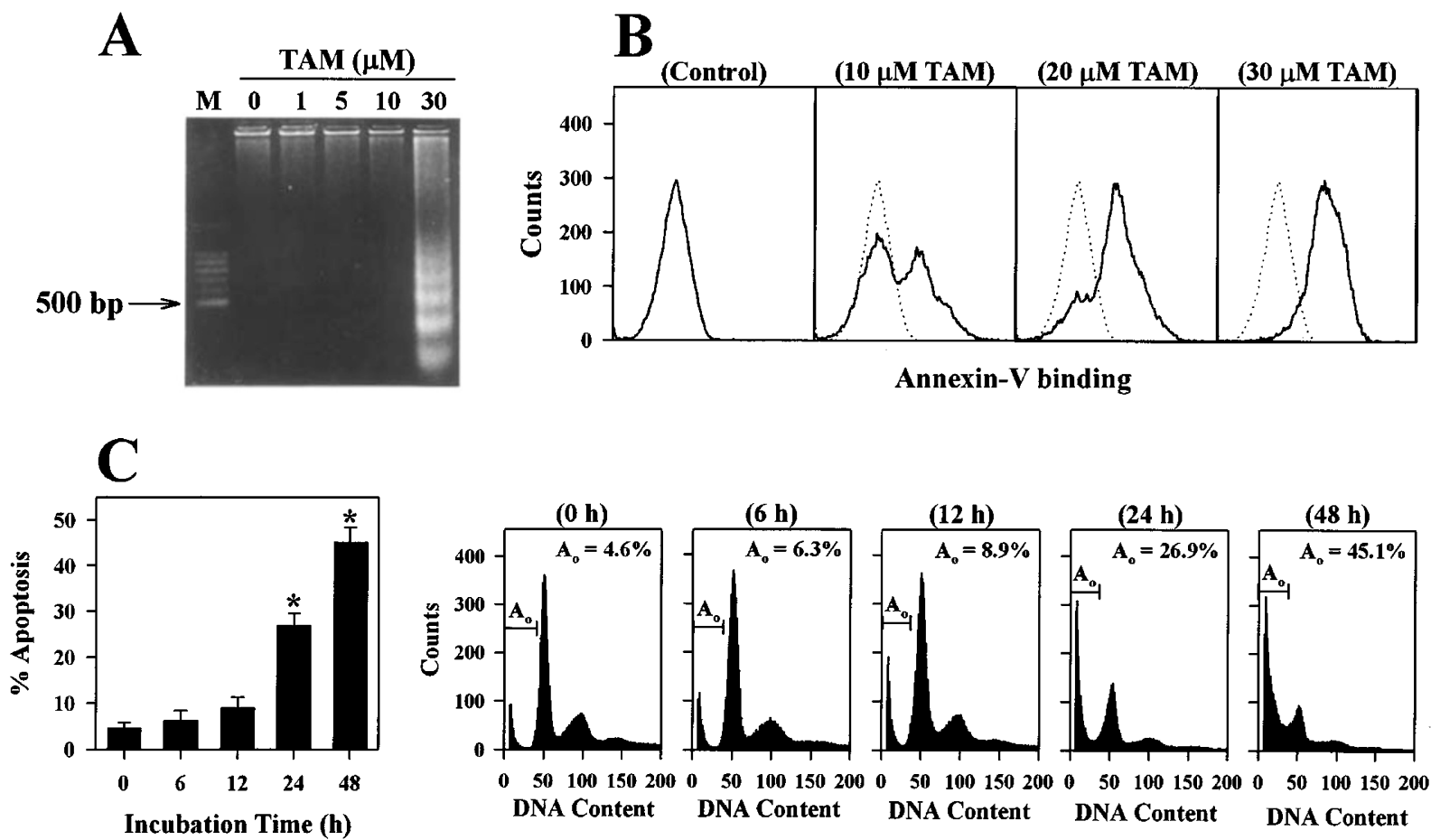

Figure 1 TAM induces apoptotic cell death in HepG2 human hepatoblastoma cells. In the experiments of $(\mathbf{A})$ cells were treated for $48 \mathrm{~h}$ with or without each concentration of TAM. DNA was isolated from the cells and analyzed by $1.8 \%$ agarose gel electrophoresis. Lane $M$ represents DNA marker. In the experiments of (B) cells were treated for $48 \mathrm{~h}$ with or without TAM $(30 \mu \mathrm{M})$. Cells were stained with Annexin-V-FLUOS and analyzed by flow cytometry. In the experiments of $(\mathbf{C})$ the cells were incubated with TAM $(30 \mu \mathrm{M})$ for each designated time. The number of apoptotic cells was measured by flow cytometry as described in text. The region to the left of the $G_{0} / G_{1}$ peak, designated $A_{0}$, was defined as cells undergoing apoptosis-associated DNA degradation. ${ }^{28}$ In bar graphs the data represent the mean values of four replications with bars indicating S.E.M. ${ }^{*} P<0.05$ compared to control 

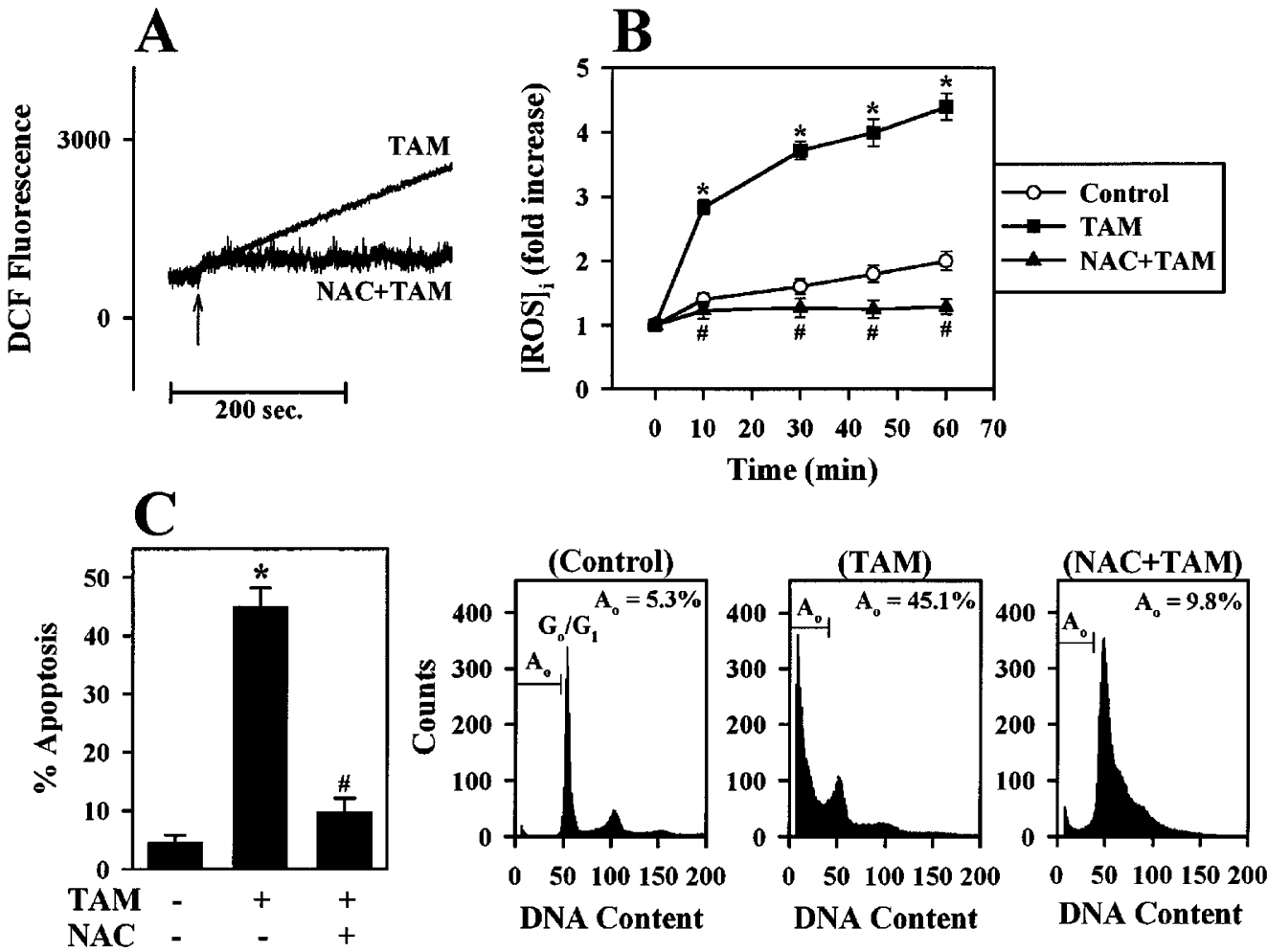

Figure 2 Effects of NAC, an antioxidant on the ROS generation ( $\mathbf{A}$ and $\mathbf{B}$ ) and apoptosis $(\mathbf{C})$ induced by TAM in HepG2 human hepatoblastoma cells. The data (A) show changes in ROS levels as a function of time, which was measured by DCF fluorescence method. ${ }^{29}$ The arrow shows the time point for addition of TAM $(30 \mu \mathrm{M})$. NAC $(50 \mathrm{mM})$ was added $10 \mathrm{~min}$ before TAM treatment. In the data (B) results are expressed as fold increase compared to the initial DCF fluorescence intensity. Data points represent the mean values for four replications with bars indicating S.E.M. ${ }^{*} P<0.05$ compared to control condition in which the cells were incubated with TAM-free medium. ${ }^{\#} P<0.05$ compared to TAM alone. In the experiments of $(\mathbf{C})$ the cells were incubated with TAM ( $\left.30 \mu \mathrm{M}\right)$ for $48 \mathrm{~h}$. NAC ( $\left.50 \mathrm{mM}\right)$ was added $30 \mathrm{~min}$ before TAM treatment. The number of apoptotic cells was measured by flow cytometry. In bar graphs the data represent the mean values of four replications with bars indicating S.E.M. ${ }^{\star} P<0.05$ compared to control. ${ }^{\#} P<0.05$ compared to TAM alone

\section{Role of intracellular $\mathrm{Ca}^{2+}$ on the ROS generation and apoptosis induced by TAM}

Next, we investigated the possible interrelationship between intracellular $\mathrm{Ca}^{2+}$ and ROS in the apoptosis-inducing activity of TAM. Time-dependent changes in the levels of intracellular $\mathrm{Ca}^{2+}$ and ROS induced by TAM $(30 \mu \mathrm{M})$ was compared with each other. Intracellular $\mathrm{Ca}^{2+}$ increase preceded the ROS generation as shown in Figure $3 \mathrm{~A}$. In addition, the TAMinduced ROS production was completely prevented by treatment with ethylene glycol-bis-(aminoethyl ether) N,N,N, $\mathrm{N}$-tetraacetic acid (EGTA) (1 mM) and bis-(o-aminophenoxy)ethane-N,N,N,N-tetraacetic acid/acetoxymethyl ester (BAPTA/AM) $(1 \mu \mathrm{M})$, an extracellular and intracellular $\mathrm{Ca}^{2+}$ chelator, respectively, as illustrated in Figure 3B. These results imply that intracellular $\mathrm{Ca}^{2+}$ may act as an early signal for the production of ROS by TAM.

\section{Role of NAD(P)H oxidase in the TAM-induced ROS generation and apoptosis}

To clarify the sites of the TAM-induced ROS production, we investigated the effects of various drugs that inhibit the mitochondrial respiratory chain enzymes or non-mitochondrial ROS-generating enzymes, on the TAM-induced ROS genera- tion and apoptosis. The results were summarized in Table 1. The effects of TAM $(30 \mu \mathrm{M})$ on the ROS level and apoptosis were not significantly altered either by inhibition of mitochondrial electron transport with inhibitors of Complex I, succinate dehydrogenase or Complex III $(10 \mu \mathrm{M}$ rotenone, $5 \mathrm{mM}$ malonate, rotenone+malonate, and $5 \mu \mathrm{M}$ antimycin $\mathrm{A}$, respectively) or by the mitochondrial uncoupler, carbonylcyanide-p(trifluoromethoxy)phenylhydrazone (FCCP) $(0.1 \mu \mathrm{M})$. These mitochondrial enzyme inhibitors did not have a significant influence on the basal level of ROS and apoptosis, except that antimycin A and FCCP significantly increased only the basal level of ROS. These results indicate that mitochondria may not be the site of ROS production induced by TAM.

Thus, we examined whether non-mitochondrial ROSgenerating enzymes contribute to the TAM-induced ROS production. The effects on the ROS and apoptosis of inhibitors of enzymes which can potentially generate ROS, cyclooxygenase, cytochrome $\mathrm{P}-450$, nitric oxide synthase, xanthine oxidase and ribonucleotide reductase $(100 \mu \mathrm{M}$ indomethacin, $500 \mu \mathrm{M}$ metyrapone, $100 \mu \mathrm{M} \mathrm{N} \mathrm{N}^{\mathrm{G}}$-monomethyl-L-arginine (NMMA), $100 \mu \mathrm{M}$ allopurinol and $1.5 \mathrm{mM}$ hydroxyurea, respectively) were tested. The results showed that all drugs tested did not significantly influence the TAMinduced ROS increase and apoptosis, implying that these enzymes may not be actively involved in the TAM effects. 
In contrast, inhibitors of membrane-bound $\mathrm{NAD}(\mathrm{P}) \mathrm{H}$ oxidase, $5 \mu \mathrm{M}$ diphenylene iodonium (DPI), ${ }^{30} 10 \mu \mathrm{M}$ phenylarsine oxide (PAO) ${ }^{31}$ and $100 \mu \mathrm{M}$ D-(+)-neopterine (NEO), ${ }^{32}$ significantly suppressed both the ROS generation and apoptosis induced by TAM as shown in Figure $4 A, B$, respectively. As a matter of fact, the activity of $N A D(P) H$ oxidase similar to that found in neutrophils, has been detected in the HepG2 cells. ${ }^{33}$ Thus, these results strongly suggest that non-phagocytic $\mathrm{NAD}(\mathrm{P}) \mathrm{H}$ oxidase may act as a major site of ROS generation induced by TAM in the HepG2 cells.

\section{Discussion}

Although anti-cancer actions of TAM have been originally known to be due to its ability to inhibit ER, ${ }^{34}$ TAM appears to be effective for many cancer cells in which ER is not expressed. ${ }^{1}$ Previously, we have reported that TAM induces apoptotic cell death in ER-negative HepG2 human hepatoma cells, ${ }^{9}$ which was confirmed in this study by DNA fragmentation assay through gel electrophoresis, measurement of hypodiploid DNA contents through flow cytometry and detection of cell-surface phosphatidylserine with annexin-V conjugates (Figure 1). However, the exact mechanism of this non-genomic action of TAM remains unclear.

The mechanism of the induction of apoptosis by TAM in ER-negative tumor cells is supposed to be related to nongenomic actions of TAM, for example, inhibition of calmodulin kinase ${ }^{35}$ or protein kinase $C .{ }^{36}$ In the HepG2 cells the TAM-induced apoptosis seems to be mediated by intracellular $\mathrm{Ca}^{2+}$ whose involvement in apoptosis has been extensively studied in various cell types. ${ }^{9,37}$ The results of this study suggest that ROS may also be involved in the TAM-induced apoptosis, since TAM generated ROS
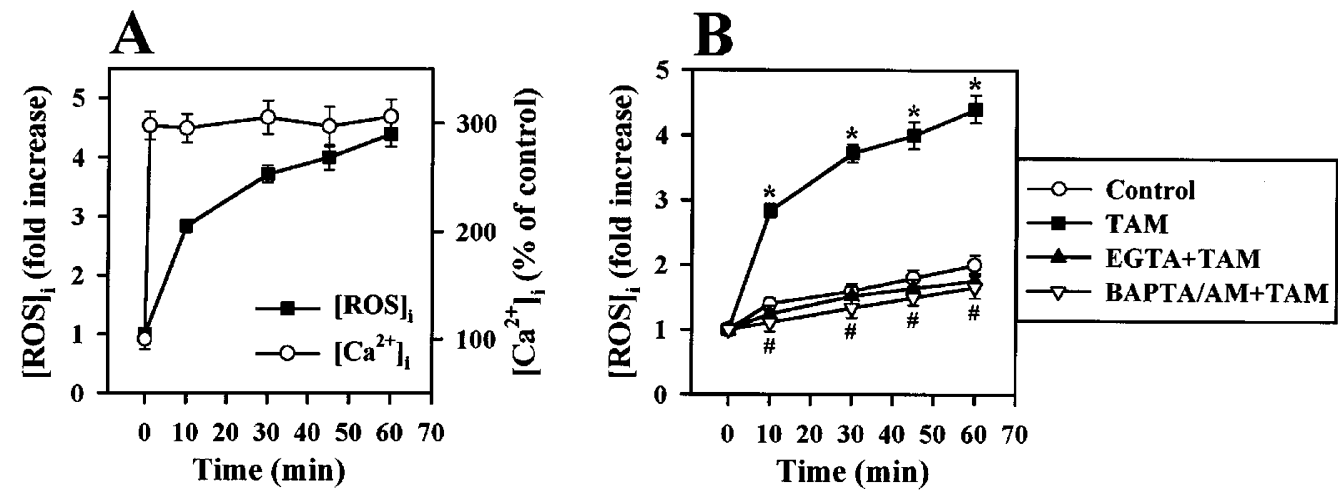

Figure 3 Role of intracellular $\mathrm{Ca}^{2+}$ in the TAM-induced ROS generation in HepG2 human hepatoblastoma cells. In the data (A) the TAM ( $\left.30 \mu \mathrm{M}\right)$-induced changes in intracellular ROS and $\mathrm{Ca}^{2+}$ levels are expressed as fold increase compared to the initial DCF fluorescence intensity and per cent of control condition in which the cells were incubated with TAM-free medium, respectively. In the data (B) the changes in intracellular ROS levels are expressed as fold increase compared to the initial DCF fluorescence intensity. EGTA $(1 \mathrm{mM})$ and BAPTA/AM $(1 \mu \mathrm{M})$ were added $10 \mathrm{~min}$ before TAM $(30 \mu \mathrm{M})$ treatment. Data points represent the mean values of four replications with bars indicating S.E.M. ${ }^{*} P<0.05$ compared to control condition in which the cells were incubated with TAM-free medium. ${ }^{\#} P<0.05$ compared to TAM alone

Table 1 Effects of inhibitors of mitochondrial respiratory chain enzymes and non-mitochondrial ROS-generating enzymes on the TAM-induced ROS generation and apoptosis in HepG2 human hepatoblastoma cells

\begin{tabular}{|c|c|c|c|c|}
\hline \multirow[b]{2}{*}{ Compound } & \multicolumn{2}{|c|}{ [ROS $_{\mathrm{i}}$ (fold increase) $^{\mathrm{a}}$} & \multicolumn{2}{|c|}{$\%$ Apoptosis $^{\text {b }}$} \\
\hline & - TAM & + TAM & - TAM & + TAM \\
\hline None & $1.2 \pm 0.1$ & $4.4 \pm 0.5^{*}$ & $5.3 \pm 0.6$ & $45.1 \pm 2.1^{*}$ \\
\hline $\begin{array}{l}\text { Mitochondrial inhibitors/un } \\
\text { Rotenone }(10 \mu \mathrm{M}) \\
\text { Malonate }(5 \mathrm{mM}) \\
\text { Rotenone+Malonate } \\
\text { Antimycin } \mathrm{A}(5 \mu \mathrm{M}) \\
\text { FCCP }(0.1 \mu \mathrm{M})\end{array}$ & $\begin{array}{l}1.1 \pm 0.1 \\
1.0 \pm 0.2 \\
1.1 \pm 0.2 \\
2.6 \pm 0.3^{*} \\
2.8 \pm 0.3^{*}\end{array}$ & $\begin{array}{l}4.1 \pm 0.4^{*} \\
4.2 \pm 0.5^{\star} \\
4.3 \pm 0.6^{*} \\
4.9 \pm 0.4^{\star} \\
5.2 \pm 0.6^{\star}\end{array}$ & $\begin{array}{l}7.8 \pm 0.7 \\
6.7 \pm 0.6 \\
6.8 \pm 0.8 \\
6.9 \pm 0.8 \\
7.8 \pm 0.9\end{array}$ & $\begin{array}{l}48.2 \pm 3.2^{\star} \\
44.7 \pm 4.5^{\star} \\
46.7 \pm 4.3^{\star} \\
45.5 \pm 3.8^{\star} \\
49.3 \pm 4.6^{\star}\end{array}$ \\
\hline $\begin{array}{l}\text { Inhibitors of ROS generat } \\
\text { Indomethacin }(100 \mu \mathrm{M}) \\
\text { Metyrapone }(500 \mu \mathrm{M}) \\
\text { NMMA }(100 \mu \mathrm{M}) \\
\text { Allopurinol }(100 \mu \mathrm{M}) \\
\text { Hydroxyurea }(1.5 \mu \mathrm{M})\end{array}$ & $\begin{array}{l}\text { es } \\
1.6 \pm 0.1 \\
1.1 \pm 0.1 \\
1.5 \pm 0.1 \\
1.5 \pm 0.1 \\
1.3 \pm 0.1\end{array}$ & $\begin{array}{l}4.2 \pm 0.5^{\star} \\
3.9 \pm 0.4^{*} \\
4.4 \pm 0.6^{\star} \\
3.9 \pm 0.7^{\star} \\
4.5 \pm 0.8^{\star}\end{array}$ & $\begin{array}{l}6.8 \pm 0.6 \\
5.9 \pm 0.9 \\
5.7 \pm 1.1 \\
6.3 \pm 1.2 \\
5.8 \pm 0.8\end{array}$ & $\begin{array}{l}50.1 \pm 4.1^{*} \\
46.9 \pm 5.3^{*} \\
42.6 \pm 3.7^{*} \\
43.8 \pm 3.9^{*} \\
45.4 \pm 4.8^{\star}\end{array}$ \\
\hline
\end{tabular}

All data represent the mean values \pm S.E.M. ${ }^{*} P<0.05$ compared to control. Note that no drug tested did significantly alter both increased $[R O S]_{i}$ and apoptosis induced by TAM. ${ }^{a}[R O S]_{i}$ was measured by DCF fluorescence method, and the values are expressed as fold increase of DCF fluorescence intensity induced by treatment with or without TAM $(30 \mu \mathrm{M})$ for $1 \mathrm{~h}$ compared to that of initial time. Each drug was added 10 min before TAM treatment. ${ }^{\mathrm{b}}$ Apoptosis was measured by flow cytometry. In the experiments the cells were incubated with TAM $(30 \mu \mathrm{M})$ for $48 \mathrm{~h}$. Each drug was added 30 min before TAM treatment 

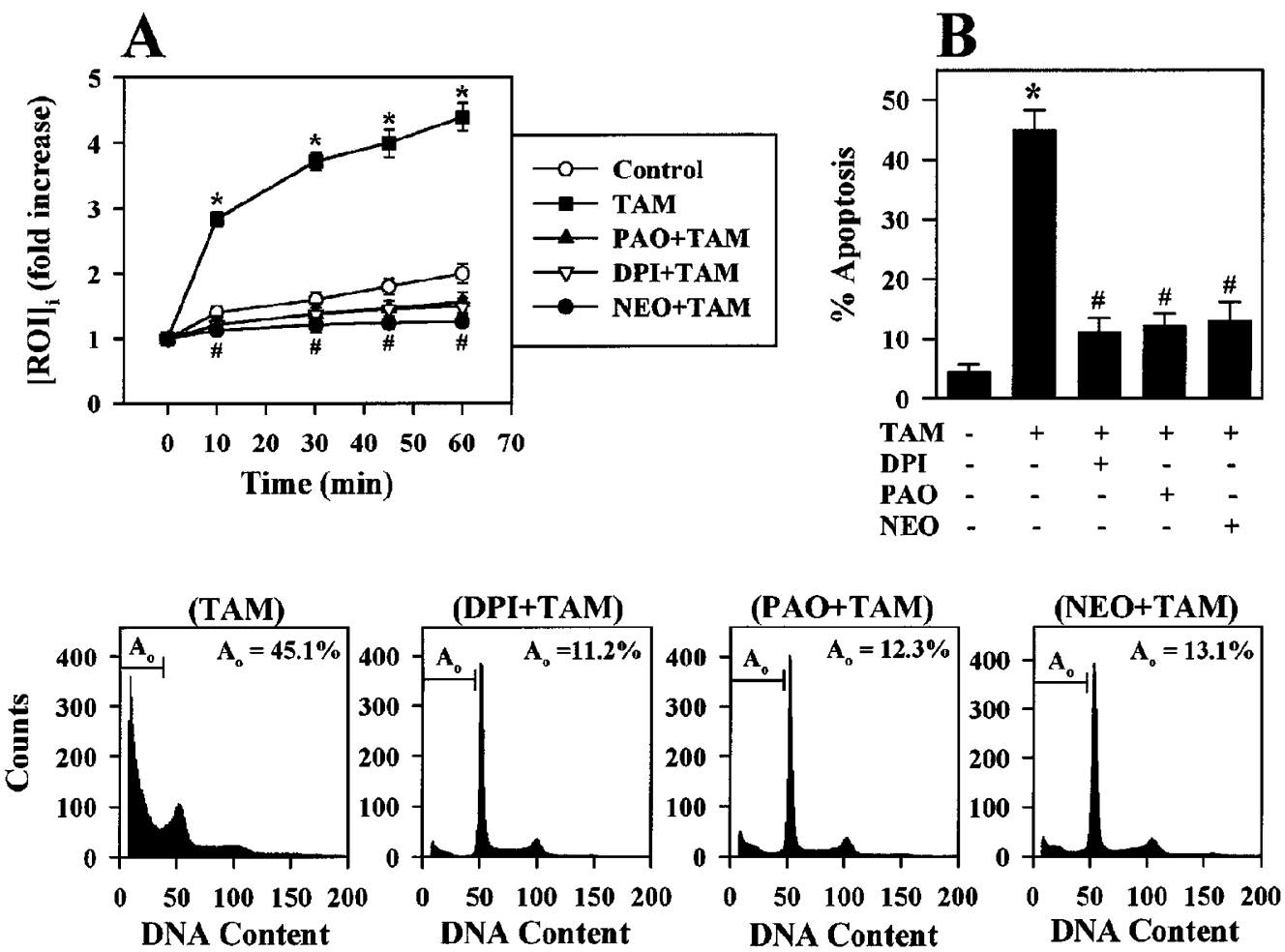

Figure 4 Effects of inhibitors of $\mathrm{NAD}(\mathrm{P}) \mathrm{H}$ oxidase on the TAM-induced ROS generation and apoptosis in HepG2 human hepatoblastoma cells. Data presentation is the same as Figure 1. In these experiments DPI $(5 \mu \mathrm{M})$. PAO $(10 \mu \mathrm{M})$ and NEO $(100 \mu \mathrm{M})$ were used. These drugs were given $10 \mathrm{~min}$ and $30 \mathrm{~min}$ before TAM application in the experiments of $(\mathbf{A})$ and $(\mathbf{B})$, respectively. ${ }^{*} P<0.05$ compared to control. ${ }^{*} P<0.05$ compared to TAM alone

(Figure 2A,B), and an antioxidant NAC significantly inhibited apoptosis induced by TAM (Figure 2C).

Since interplay between intracellular $\mathrm{Ca}^{2+}$ and ROS has been shown in many cellular systems, ${ }^{38,39}$ we hypothesized that there is a cause-and-effect relationship between intracellular $\mathrm{Ca}^{2+}$ and ROS as a mediator of the TAMinduced apoptosis in the HepG2 cells. The results of the present study strongly suggest that ROS may be a downstream signal of elevated intracellular $\mathrm{Ca}^{2+}$. The TAM-induced generation of ROS was preceded by elevation of intracellular $\mathrm{Ca}^{2+}$ in a time frame (Figure $3 \mathrm{~A}$ ), and completely inhibited by reducing extracellular $\mathrm{Ca}^{2+}$ concentration with a nominal $\mathrm{Ca}^{2+}$-free medium containing EGTA and chelating intracellular $\mathrm{Ca}^{2+}$ with BAPTA/AM (Figure 3B).

The major biological process leading to oxygen-derived ROS generation is electron transport associated with mitochondrial membranes. ${ }^{40}$ In mitochondria complex III can generate ROS, especially in the presence of compounds that prolong the lifetime of ubisemiquinone. ${ }^{14}$ Therefore, if the site of the TAM-induced ROS increase is mitochondria, mitochondrial inhibitors that suppress the formation of ubisemiquinone at complex III should abolish the increase in ROS seen by treating with TAM. However, rotenone and malonate (inhibitors of NADH dehydrogenase and succinate dehydrogenase, respectively) treated alone or together, did not have a significant influence on the TAM-induced ROS generation and apoptosis (Table 1). As expected, antimycin A, a complex III inhibitor augmented the basal production of ROS probably through prolonging the lifetime of ubisemiquinone, ${ }^{41}$ but it did not enhance the ROS production and apoptosis induced by TAM (Table 1). In addition, FCCP, a mitochondrial uncoupler also increased the basal ROS level, which is consistent with the results of other studies, ${ }^{42}$ but it had no effect on the TAM-induced ROS production and apoptosis. Taken together, these results strongly suggest that mitochondria may not be the site of ROS generation induced by TAM.

ROS can also be generated by non-mitochondrial sites. ROS appear to be produced by the microsomal enzyme, cytochrome P-450, and numerous catalytic cytosolic enzymes, including cyclooxygenase, nitric oxide synthase, xanthine oxidase and ribonucleotide reductase. ${ }^{43}$ The specific inhibitors of these enzymes (500 $\mu \mathrm{M}$ metyrapone, $100 \mu \mathrm{M}$ indomethacin, $100 \mu \mathrm{M}$ NMMA, $100 \mu \mathrm{M}$ allopurinol and $1.5 \mathrm{mM}$ hydroxyurea, respectively) were not effective for preventing the TAM-induced ROS production and apoptosis (Table 1), demonstrating that these nonmitochondrial enzymes may not be involved in the ROS generation by TAM in the HepG2 cells.

The membrane-bound NADPH oxidase is known to produce ROS during the respiratory burst in neutrophils. ${ }^{44}$ The enzyme has also been involved in the ROS-mediated apoptosis in human leukemia cells. ${ }^{45}$ The activation of this enzyme proceeds through a multistep assembly at the plasma membrane of several components including the two subunits of cytochrome $b_{558}\left(\mathrm{p} 22^{\text {phox }}\right.$ and gp91 ${ }^{\text {phox }}$ ), the small GTP. binding proteins (Rac and Rap1A), and the cytosolic factors 
(p40 ${ }^{\text {phox }}$, p47 $7^{\text {phox }}$ and p67 $\left.7^{\text {phox }}\right){ }^{44,46}$ Recently, these components have also been detected and functionally active in nonphagocytic cells, including endothelial cells, ${ }^{47}$ vascular smooth muscle cells, ${ }^{48}$ neuroepithelial bodies of the lung ${ }^{49}$ and type I cells of the carotid body. ${ }^{50}$ Interestingly, this enzyme acts as a main system to produce ROS during oxidative stress condition in vascular cells. ${ }^{51,52}$

HepG2 cells used in this study have been shown to express these components found in the NADPH oxidase complex of neutrophils. ${ }^{53,54}$ This enzyme system appears to be a major source of ROS produced particularly in association with hypoxia-induced erythropoietin expression in the HepG2 cells. ${ }^{53}$ Therefore, we examined whether the membrane-bound $\mathrm{NAD}(\mathrm{P}) \mathrm{H}$ oxidase contributes to the TAM-induced ROS generation. The significant suppression of the TAM-induced production of ROS (Figure $4 \mathrm{~A}$ ) and apoptosis (Figure 4B) by various inhibitors of the enzyme (DPI, PAO and NEO) suggest that the membrane-bound $\mathrm{NAD}(\mathrm{P}) \mathrm{H}$ oxidase may be actively involved in the production of ROS induced by TAM.

Currently, we do not know the exact mechanism by which TAM activates the $\mathrm{NAD}(\mathrm{P}) \mathrm{H}$ oxidase in the HepG2 cells. However, antagonistic effects of $\mathrm{Ca}^{2+}$ inhibitors on the TAM-induced ROS generation (Figure 3B) suggest involvement of intracellular $\mathrm{Ca}^{2+}$ signal. Recently, Cool et al. ${ }^{54}$ have demonstrated that in HepG2 cells Rac1, a small GTP binding protein is involved in the regulation of ROS production by the non-phagocytic $\mathrm{NAD}(\mathrm{P}) \mathrm{H}$ oxidase complex. In addition, $\mathrm{Ca}^{2+} / \mathrm{CaM}$-dependent protein kinaseII has been demonstrated to phosphorylate and regulate Tiam1, ${ }^{55}$ a Rac1-specific exchange factor. ${ }^{56}$ Thus, although speculated, there is a possibility that elevated $\mathrm{Ca}^{2+}$ by TAM activates $\mathrm{Ca}^{2+} / \mathrm{CaM}$-dependent protein kinase-II, which in turn, activates Tiam1, leading to activation of Rac1. Moreover, Orie et al. ${ }^{57}$ have recently found that $\mathrm{Ca}^{2+}$ / CaM-dependent protein kinase-II is a common signaling component in the generation of ROS in human lymphocytes. The involvement of $\mathrm{Ca}^{2+} / \mathrm{CaM}$-dependent protein kinase-II in the TAM-induced activation of $\mathrm{NAD}(\mathrm{P}) \mathrm{H}$ oxidase in the HepG2 cells remains to be elucidated in the future.

In conclusion, TAM induced apoptosis through generation of ROS in HepG2 human hepatoblastoma cells. TAM may activate $\mathrm{NAD}(\mathrm{P}) \mathrm{H}$ oxidase via increasing intracellular $\mathrm{Ca}^{2+}$ concentration, which results in the production of ROS and apoptosis. However, since the concentration of tamoxifen used in this study (30 $\mu \mathrm{M})$ may not be obtainable in vivo, one should consider it cautiously when these results may be interpreted as the mechanism of the actions of tamoxifen in vivo. Nevertheless, these results suggest that $\mathrm{NAD}(\mathrm{P}) \mathrm{H}$ oxidase may have a novel role in apoptotic cell death induced by TAM, an activator of intracellular $\mathrm{Ca}^{2+}$ signal in the HepG2 cells.

\section{Materials and Methods}

\section{Materials}

The powders Eagle's minimum essential medium (MEM) and Earle's basal salt solution, trypsin solution (EBSS), EGTA, TAM, NAC, rotenone, malonate, antimycin $A$, indomethacin, metyrapone, allopur- inol, NMMA, FCCP, hydroxyurea, DPI, PAO, NEO, sodium pyruvate, probenecid, $\mathrm{PI}$, ribonuclease $\mathrm{A}$ and all salt powders were obtained from Sigma Chemical Co. (St. Louis, MO, USA). 1-(2,5-Carboxyoxazol-2-yl-6-aminobenzfuran-5-oxyl)-2-(2'-amino-methylphenoxy)ethane-N,N,N,N-tetraacetoxylmethyl ester (Fura-2/AM), BAPTA/AM and DCFH-DA were from Molecular Probes, Inc. (Eugene, OR, USA). Fetal bovine serum (FBS) and antibiotics (penicillin and streptomycin mixture) were purchased from GIBCO (Grand Island, NY, USA). Fura2/AM, BAPTA/AM and DCFH-DA were prepared as stock solutions in dimethyl sulfoxide (DMSO), then diluted with aqueous medium to the final desired concentrations. The stock solutions of drugs were sterilized by filtration through $0.2 \mu \mathrm{m}$ disc filters (Gelman Sciences: Ann Arbor, MI, USA).

\section{Cell line and cell culture}

HepG2 human hepatoblastoma cell line was purchased from American Type Culture Collection (Rockville, MA, USA). HepG2 cells were grown at $37^{\circ} \mathrm{C}$ in a humidified incubator under $5 \% \mathrm{CO}_{2} / 95 \%$ air in a MEM supplemented with $10 \%$ FBS, $200 \mathrm{IU} / \mathrm{ml}$ penicillin, $200 \mu \mathrm{g} / \mathrm{ml}$ of streptomycin and $1 \mathrm{mM}$ sodium pyruvate. Culture medium was replaced every other day. After attaining confluence the cells were subcultured following trypsinization.

\section{DNA isolation and electrophoresis}

DNA isolation was done according to Hockenbery et al. ${ }^{58}$ HepG2 cells were collected by centrifugation $(200 \times g, 10 \mathrm{~min})$, washed twice in phosphate buffered saline (PBS) $(\mathrm{pH} 7.4)$ and resuspended at a density of $4 \times 10^{6}$ cells $/ 400 \mu \mathrm{l}$ in hypotonic lysing buffer $(5 \mathrm{mM}$ Tris, $20 \mathrm{mM}$ EDTA, pH 7.4) containing $0.5 \%$ Triton $\mathrm{X}-100$ for 30 min at $4^{\circ} \mathrm{C}$. The lysates were centrifuged at $13000 \times g$ for $15 \mathrm{~min}$ at $4^{\circ} \mathrm{C}$. Fragmented DNA was extracted from the supernatant with phenolchloroform-isoamylalcohol, precipitated by addition of 2 volume of absolute ethanol and 0.1 volume of $3 \mathrm{mM}$ sodium acetate, and treated with RNAse A $(500 \mathrm{U} / \mathrm{ml})$ at $37^{\circ} \mathrm{C}$ for $3 \mathrm{~h}$. The pattern of DNA fragmentation was visualized by electrophoresis in $1.8 \%$ agarose gel containing ethidium bromide and photographed under UV light.

\section{Intracellular ROS measurement}

Relative changes in intracellular ROS in the HepG2 cells were monitored using a fluorescent probe, DCFH-DA. ${ }^{29}$ DCFH-DA diffuses through the cell membrane readily and is hydrolyzed by intracellular esterases to nonfluorescent DCFH, which is then rapidly oxidized to highly fluorescent DCF in the presence of ROS. The DCF fluorescence intensity is proportional to the amount of ROS formed intracelularly. ${ }^{59}$ Cells were washed twice and resuspended at a concentration of $4 \times 10^{5}$ cells $/ \mathrm{ml}$ in Hank's solution. For loading DCFH-DA into the cells, cells were incubated with the dye for $2 \mathrm{~h}$ at a final concentration of $5 \mu \mathrm{M}$ at $37^{\circ} \mathrm{C}$. Fluorescence (excitation wavelength set at $485 \mathrm{~nm}$ and the emission wavelength at $530 \mathrm{~nm}$ ) was monitored in a well-stirred cuvette.

\section{Intracellular $\mathrm{Ca}^{2+}$ measurement}

Aliquots of the HepG2 cells were washed in EBSS. Then, $5 \mu \mathrm{M}$ Fura-2 was added, and the cells were incubated for $30 \mathrm{~min}$ at $37^{\circ} \mathrm{C}$. Unloaded Fura-2 was removed by centrifugation at $150 \times g$ for $3 \mathrm{~min}$. Cells were resuspended at a density of $2 \times 10^{6} \mathrm{cells} / \mathrm{ml}$ in Krebs-Ringer buffer containing $125 \mathrm{mM} \mathrm{NaCl}, 5 \mathrm{mM} \mathrm{KCl}, 1.3 \mathrm{mM} \mathrm{CaCl}_{2}, 1.2 \mathrm{mM} \mathrm{KH}_{2} \mathrm{PO}_{4}$, $1.2 \mathrm{mM} \mathrm{MgSO}_{4}, 5 \mathrm{mM} \mathrm{NaHCO}_{3}, 25 \mathrm{mM}$ HEPES, $6 \mathrm{mM}$ glucose and $2.5 \mathrm{mM}$ probenecid ( $\mathrm{pH}$ 7.4). Fura-2-loaded cells were maintained at 
$25^{\circ} \mathrm{C}$ for $90 \mathrm{~min}$ before fluorescence measurement. For each experiment, $0.5 \mathrm{ml}$ aliquot of Fura-2-loaded cells was equilibrated to $37^{\circ} \mathrm{C}$ in a stirred quartz cuvette. Fluorescence emission $(510 \mathrm{~nm})$ was monitored with the excitation wavelength cycling between 340 and $380 \mathrm{~nm}$ using a Hitachi F4500 fluorescence spectrophotometer. At the end of an experiment, fluorescence maximum and minimum values at each excitation wavelength were obtained by lysis of cells with $20 \mu \mathrm{g} /$ $\mathrm{ml}$ digitonin (maximum) and then adding $10 \mathrm{mM}$ EGTA (minimum). With the maximum and minimum values, the $340: 380 \mathrm{~nm}$ fluorescence ratios were converted into free $\mathrm{Ca}^{2+}$ concentrations using a software, F-4500 Intracellular Cation Measurement System, provided by Hitachi.

\section{Flow cytometric analysis of apoptosis}

For flow cytometry analysis, HepG2 cells were collected and washed twice with PBS buffer (pH 7.4). After fixing in $80 \%$ ethanol for $30 \mathrm{~min}$, cells were washed twice, and resuspended in PBS buffer ( $\mathrm{pH} 7.4$ ) containing $0.1 \%$ Triton X-100, $5 \mu \mathrm{g} / \mathrm{ml} \mathrm{PI}$ and $50 \mu \mathrm{g} / \mathrm{ml}$ ribonuclease $A$ for DNA staining. Cells were then analyzed by a FACScan (BIO-RAD, Hercules, CA, USA). At least 20000 events were evaluated. All histograms were analyzed using WinBryte software (BIO-RAD, Hercules, CA, USA) to determine percentage of nuclei with hypodiploid content indicative of apoptosis. ${ }^{28}$

The normal lipid organization of the plasma membrane is altered soon after apoptosis is initiated. Thus, annexin- $V$ binding was also employed as an indicator of apoptosis ${ }^{60}$ to demonstrate the loss of phospholipid asymmetry and the presence of phosphatidylserine on the outer layer of the plasma membrane. It was analyzed using a commercial kit (Boehringer Mannheim Biochemicals, Mannheim, Germany). Cells were washed in cold PBS, and resuspended in binding buffer. A portion of cell suspension $(500 \mu \mathrm{l})$ was exposed to Annexin-V-FLUOS. The cells were gently vortexed, incubated at room temperature for 20 min in the dark, and then analyzed by FACScan within $1 \mathrm{~h}$ of staining.

\section{Data analysis}

All experiments were performed four times. Data were expressed as mean \pm standard error of the mean (S.E.M.) and were analyzed using one way analysis of variance (ANOVA) and Student-Newman-Keul's test for individual comparisons. $P$ values less than 0.05 are considered statistically significant.

\section{Acknowledgements}

This work was supported by the Yeungnam University Research Grant in 2000 to J-A Kim.

\section{References}

1. Jordan VC (1990) Long-term adjuvant tamoxifen therapy for breast cancer. Breast Cancer Res. Treat. 15: 125-136

2. Nayfield SG, Karp JE, Ford LG, Dorr FA and Kramer BS (1991) Potential role of tamoxifen in prevention of breast cancer. J. Natl. Cancer Inst. 83: 1450-1459

3. Kon OL (1989) Estrogens, antiestrogens and cell proliferation. Bioessays. 10: $210-214$

4. Kidd VJ (1998) Proteolytic activities that mediate apoptosis. Annu. Rev. Physiol. 60: $533-573$
5. Keen JC, Dixon JM, Miller EP, Cameron DA, Chetty U, Hanby A, Bellamy C and MillerWR (1997) The expression of Ki-S1 and BCL-2 and the response to primary tamoxifen therapy in elderly patients with breast cancer. Breast Cancer Res. Treat. 44: $123-133$

6. Ellis PA, Saccani-Jotti G, Clarke R, Johnston SR, Anderson E, Howell A, A'Hern R, Salter J, Detre S, Nicholson R, Robertson J, Smith IE and Dowsett M (1997) Induction of apoptosis by tamoxifen and $\mathrm{ICl} 182780$ in primary breast cancer. Int. J. Cancer 72: 608-613

7. Ferlini C, Scambia G, Marone M, Distefano M, Gaggini C, Ferrandina G, Fattorossi A, Isola G, Benedetti Panici P and Mancuso S (1999) Tamoxifen induces oxidative stress and apoptosis in oestrogen receptor-negative human cancer cell lines. Br. J. Cancer 79: 257-263

8. Kang Y, Cortina R and Perry RR (1996) Role of c-myc in tamoxifen-induced apoptosis estrogen-independent breast cancer cells. J. Natl. Cancer Inst. 88: $279-284$

9. Kim JA, Kang YS, Lee SH, Lee EH and Lee YS (1999) Involvement of $\mathrm{Ca}^{2+}$ influx in the mechanism of tamoxifen-induced apoptosis in HepG2 human hepatoblastoma cells. Cancer Lett. 147: 115-123

10. McConkey DJ and Orrenius S (1996) The role of calcium in the regulation of apoptosis. J. Leukoc. Biol. 59: 775-783

11. Bonnefoy-Berard N, Genestier L, Flacher M and Revillard JP (1994) The phosphoprotein phosphatase calcineurin controls calcium-dependent apoptosis in B cell lines. Eur. J. Immunol. 24: 325-329

12. Shibasaki $F$, Kondo $E$, Akagi $E$ and McKeon $F$ (1997) Suppression of signaling through NF-AT by interactions between calcineurin and BCL-2. Nature 386: $728-731$

13. Squier MKT and Cohen JJ (1997) Calpain, an upstream regulator of thymocyte apoptosis. J. Immunol. 158: 3690-3697

14. Wyllie AH, Morris RG, Smith AL and Dunlop D (1984) Chromatin cleavage in apoptosis: Association with condensed chromatin morphology and dependence on macromolecular synthesis. J. Pathol. 142: 67

15. Fesus L, Thomazy V and Falus A (1987) Induction and activation of tissue transglutaminase during programmed cell death. FEBS Lett. 224: 104-108

16. Cohen JJ and Duke RC (1984) Glucocorticoid activation of a calcium-dependent endonuclease in thymocyte nuclei leads to cell death. J. Immunol. 132: 38-42

17. Melino G, Annicchiarico-Petruzzeli M, Piredda L, Candi E, Gentile V, Davies PJ and Piacentini M (1994) Tissue transglutaminase and apoptosis: Sense and antisense transfection studies with human neuroblastoma cells. Mol. Cell. Biol. 14: $6584-6596$

18. Jain PT and Trump BF (1997) Tamoxifen induces deregulation of $\left[\mathrm{Ca}^{2+}\right]$ in human breast cancer cells. Anticancer Res. 17: 1167-1174

19. Gardner AM, Xu FH, Fady C, Jacoby FJ, Duffey DC, Tu Y and Lichtenstein A (1997) Apoptotic vs. nonapoptotic cytotoxicity induced by hydrogen peroxide. Free Radic.Biol. Med. 22: 73-83

20. Jayanthi S, Ordonez S, McCoy MT and Cadet JL (1999) Dual mechanism of Fasinduced cell death in neuroglioma cells: a role for reactive oxygen species. Brain Res. Mol. Brain Res. 72: 158-165

21. Hildeman DA, Mitchell T, Teague TK, Henson P, Day BJ, Kappler J and Marrack PC (1999) Reactive oxygen species regulate activation-induced T cell apoptosis. Immunity 10: 735-744

22. KamataHand HirataH (1999) Redox regulation of cellular signalling. Cell. Signal 11: $1-14$

23. Hayon T, Dvilansky A, Oriev L and Nathan I (1999) Non-steroidal antiestrogens induce apoptosis in $\mathrm{HL} 60$ and MOLT3 leukemic cells; involvement of reactive oxygen radicals and protein kinase C. Anticancer Res. 19: 2089-2093

24. Orie NN, Zidek W and Tepel M (1999) Chemoattractant- and mitogen-induced generation of reactive oxygen species in human lymphocytes: the role of calcium. Exp. Physiol. 84: 515-520

25. Goldman R, Moshonov S and Zor U (1998) Generation of reactive oxygen species in a human keratinocyte cell line: role of calcium. Arch. Biochem. Biophys. 350: 10-18

26. Khalfi F, Gressier B, Brunet C, Dine T, Luyckx M, Cazin M and Cazin JC (1996) Involvement of the extracellular calcium in the release of elastase and the human neutrophils oxidative burst. Cell. Mol. Biol. 42: 1211-1218

27. Boldyrev AA, Carpenter DO, Huentelman MJ, Peters CM and Johnson P (1999) Sources of reactive oxygen species production in excitotoxin-stimulated cerebellar granule cells. Biochem. Biophys. Res. Commun. 256: 320-324 
28. Bombeli T, Karsan A, Tait JF and Harlan JM (1997) Apoptotic vascular endothelial cells become procoagulant. Blood 89: 2429-2442

29. LaBel CP, Ischiopoulos $H$ and Bondy SC (1992) Evaluation of the probe $2^{\prime}, 7^{\prime}$ dichlorofluorescin as an indicator of reactive oxygen species formation and oxidative stress. Chem. Res. Toxicol. 5: 227-231

30. O'Donnell BV, Tew DG, Jones OT and England PJ (1993) Studies on the inhibitory mechanism of iodonium compounds with special reference to neutrophil NADPH oxidase. Biochem. J. 290: 41-49

31. Le Cabec V and Maridonneau-Parini I (1995) Complete and reversible, inhibition of NADPH oxidase in human neutrophils by phenylarsine oxide at a step distal to membrane translocation of the enzyme subunits. J. Biol. Chem. 270: $2067-$ 2073

32. Kojima S, Nomura T, Icho T, Kajiwara Y, Kitabatake K and Kubota K (1993) Inhibitory effect of neopterin on NADPH-dependent superoxide-generating oxidase of rat peritoneal macrophages. FEBS Lett. 329: 125-128

33. Ehleben W, Porwol T, Fandrey J, Kummer W and Acker H (1997) Cobalt and desferrioxamine reveal crucial members of the oxygen sensing pathway in HepG2 cells. Kidney Int. 51: 483-491

34. MacGregor $\mathrm{Jl}$ and Jordan VC (1998) Basic guide to the mechanisms of antiestrogen action. Pharmacol. Rev. 50: 151-196

35. Rowlands MG, Parr IB, McCague R, Jarman M and Goddard PM (1990) Variation of the inhibition of calmodulin dependent cyclic AMP phosphodiesterase amongst analogues of tamoxifen; correlations with cytotoxicity. Biochem. Pharmacol. 40: 283-289

36. Cheng AL, Chuang SE, Fine RL, Yeh KH, Liao CM, Lay JD and Chen DS (1998) Inhibition of the membrane translocation and activation of protein kinase $\mathrm{C}$, and potentiation of doxorubicin-induced apoptosis of hepatocellular carcinoma cells by tamoxifen. Biochem. Pharmacol. 55: 523-531

37. Distelhorst CW and Dubyak G (1998) Role of calcium in glucocorticosteroidinduced apoptosis of thymocytes and lymphoma cells: resurrection of old theories by new findings. Blood 91: 731-734

38. Supinski G, Nethery D, Stofan D and DiMarco A (1999) Extracellular calcium modulates generation of reactive oxygen species by the contracting diaphragm. J. Appl. Physiol. 87: 2177-2185

39. Bae GU, Seo DW, Kwon HK, Lee HY, Hong S, Lee ZW, Ha KS, Lee HW and Han JW (1999) Hydrogen peroxide activates p70(S6k) signaling pathway. J. Biol. Chem. 274: 32596-32602

40. Halliwell B (1989) Free radicals, reactive oxygen species and human disease: a critical evaluation with special reference to atherosclerosis. Br. J. Exp. Pathol. 70: $737-757$

41. Garcia-Ruiz C, Colell A, Morales A, Kaplowitz N and Fernandez-Checa JC (1995) Role of oxidative stress generated from the mitochondrial electron transport chain and mitochondrial glutathione status in loss of mitochondria function and activation of transcription factor nuclear factor-kappa B: studies with isolated mitochondria and rat hepatocytes. Mol. Pharmacol. 48: 825-834

42. Dugan LL, Sensi SL, Canzoniero LM, Handran SD, Rothman SM, Lin TS, Goldberg MP and Choi DW (1995) Mitochondrial production of reactive oxygen species in cortical neurons following exposure to $\mathrm{N}$-methyl-D-aspartate. J. Neurosci. 15: 6377-6388

43. Yu BP (1994) Cellular defenses against damage from reactive oxygen species. Physiol. Rev. 74: 139-162
44. Babior BM (1995) The respiratory burst oxidase. Curr. Opin. Hematol. 2: 55-60

45. Hiraoka W, Vazquez N, Nieves-Neira W, Chanock SJ and Pommier Y (1998) Role of oxygen radicals generated by NADPH oxidase in apoptosis induced in human leukemia cells. J. Clin. Invest. 102: 1961-1968

46. Babior BM (1999) NADPH oxidase: an update. Blood 93: 1464-1476

47. Jones SA, O'Donnell VB, Wood JD, Broughton JP, Hughes EJ and Jones OT (1996) Expression of phagocyte NADPH oxidase components in human endothelial cells. Am. J. Physiol. 271: H1626-H1634

48. Marshall C, Mamary AJ, Verhoeven AJ and Marshall BE (1996) Pulmonary artery $\mathrm{NADPH}$-oxidase is activated in hypoxic pulmonary vasoconstriction. Am. J. Respir. Cell Mol. Biol. 15: 633-644

49. Youngson C, Nurse C, Yeger H, Curnutte JT, Vollmer C, Wong V and Cutz E (1997) Immunocytochemical localization on O2-sensing protein (NADPH oxidase) in chemoreceptor cells. Microsc. Res. Tech. 37: 101-106

50. Kummer W and Acker H (1995) Immunohistochemical demonstration of four subunits of neutrophil $\mathrm{NAD}(\mathrm{P}) \mathrm{H}$ oxidase in type I cells of carotid body. J. Appl. Physiol. 78: 1904-1909

51. Kashiwagi A, Shinozaki K, Nishio Y, Maegawa H, Maeno Y, Kanazawa A, Kojima H, Haneda M, Hidaka H, Yasuda H and Kikkawa R (1999) Endothelium-specific activation of $\mathrm{NAD}(\mathrm{P}) \mathrm{H}$ oxidase in aortas of exogenously hyperinsulinemic rats. Am. J. Physiol. 77: E976-E983

52. Brandes RP, Koddenberg G, GwinnerW, Kim DY, Kruse HJ, Busse Rand Mugge A (1999) Role of increased production of superoxide anions by NAD(P)H oxidase and xanthine oxidase in prolonged endotoxemia. Hypertension 33: 1243-1249

53. Ehleben W, Porwol T, Fandrey J, Kummer W and Acker H (1997) Cobalt and desferrioxamine reveal crucial members of the oxygen sensing pathway in HepG2 cells. Kidney Int. 51: 483-491

54. Cool RH, Merten E, Theiss C and AckerH (1998) Rac1, and not Rac2, is involved in the regulation of the intracellular hydrogen peroxide level in HepG2 cells. Biochem. J. 332: 5-8

55. Fleming IN, Elliott CM, Buchanan FG, Downes CP and Exton JH (1999) $\mathrm{Ca}^{2+}$ calmodulin-dependent protein kinase II regulates Tiam1 by reversible protein phosphorylation. J. Biol. Chem. 274: 12753-12758

56. Collard JG, Habets GG, Michiels F, Stam J, van der Kammen RA and van Leeuwen $F(1996)$ Role of Tiam1 in Rac-mediated signal transduction pathways. Curr. Top. Microbiol. Immunol. 213: 253-265

57. Orie NN, Zidek W and Tepel M (1999) Tyrosine and calcium/calmodulin kinases are common signaling components in the generation of reactive oxygen species in human lymphocytes. Life Sci. 65: 2135-2142

58. Hockenbery D, Nunez G, Milliman C, Schreiber RD and Korsmeyer SJ (1990) $\mathrm{BCl}-2$ is an inner mitochondrial membrane protein that blocks programmed cell death. Nature 348: 334-336

59. Shen HM, Shi CY and Ong CN (1996) Detection of elevated reactive oxygen species level in cultured rat hepatocytes treated with aflatoxin B1. Free Radic. Biol. Med. 21: 139-146

60. Vermes I, Haanen C, Steffens-Nakken H and Reutelingsperger C (1995) A novel assay for apoptosis. Flow cytometric detection of phosphatidylserine expression on early apoptotic cells using fluorescein labelled Annexin V. J. Immunol. Methods 184: $39-51$ 